DE DE GRUYTER OPEN
ACTA ENVIRONMENTALICA

UNIVERSITATIS COMENIANAE (BRATISLAVA)

ISSN 1339-9802 (online)

\title{
ON THE OCCURRENCE OF THE INTRODUCED PEST THRIPS SIMPLEX (MORISON 1930) (THYSANOPTERA: THRIPIDAE) IN SLOVAKIA
}

\author{
Rudolf Masarovič, Martina Zvaríková, Jakub Sigmund \& Peter Fedor \\ Department of Environmental Ecology, Faculty of Natural Sciences, Comenius University in Bratislava, \\ Mlynská dolina, Ilkovičova 6, 84215 Bratislava, Slovak Republic \\ Corresponding author: Rudolf Masarovič (e-mail: rudolf.masarovic@uniba.sk)
}

\begin{abstract}
Exotic species introduction has recently increased European insect diversity in accordance with global climate change and international biological commodity trade, often with serious environmental and economic consequences for natural ecosystems as well as urban and farmland area. This short communication deals with the first official faunistic record of the gladiolus thrips Thrips simplex (Morison, 1930) (Thysanoptera, Thripidae) in Slovakia.
\end{abstract}

Key words: Gladiolus thrips, Slovakia, pest, Thrips simplex, Thysanoptera

Recommended form of citation: Masarovič, R., Zvariková, M., Sigmund, J. \& Fedor, P., 2016. On the Occurrence of the Introduced Pest Thrips simplex (Morison 1930) (Thysanoptera: Thripidae) in Slovakia. Acta Environ. Univ. Comenianae (Bratislava). 24(1): 38-41.

DOI: 10.1515/aeuc-2016-0005

\section{INTRODUCTION}

Introduced exotic species have recently increased European insect diversity, often with serious environmental and economic consequences for natural ecosystems as well as urban and farmland area. Approximately 580 thrips (Thysanoptera) species, including the pests with invasive and economic potential, are known from Europe (ZUR STRASSEN 2003), however, the species richness has grown up due to the synergic complex of many natural and human-induced phenomena (GOLDARAZENA 2011; KARADJOVA \& KRUMOV 2003; RODIKATIS et al. 2006; TRDAN et al. 2003, 2005; VIERBERGEN et al. 2006; FEDOR \& VARGA 2007; VARGA 2008; VARGA \& FEDOR 2008, etc.). Exotic species, originally from tropical and subtropical regions, can more easily spread into temperate countries, especially due to the globalized trade with biological commodities and global climate change (COLLINS 1998; FEDOR \& VARGA 2007; JENSER \& CZENZ 1988; LEWIS 1997; PELIKÁN 1989, 1991; VARGA \& FEDOR 2008; VIERBERGEN et al. 2006; VIERBERGEN \& DE JONG 2013), continuously adapt to local climatic and 
ecological conditions and even expand to other regions (MASAROVIČ et al. 2014). Research on their ecology, distribution and invasion potential is often a key to reduce consequential economic damage.

The gladiolus thrips was firstly described by Morison (1930) as Physothrips simplex from flowers of Dianthus carryophylus (Urrbrae, South Australia). Its origin still remains discussed (MORISON 1957; LEWIS 1973; MOUND 1997). The species has now rather cosmopolitan distribution and is found wherever Gladiolus plants are grown or cultivated: in Africa, southern Asia and Japan, Australia, several Pacific Islands, Europe and North and South America (DENMARK \& PRICE 1998). It occurs mostly on Gladiolus cultivars, but also on Calla sp., Pancratium sp., Protea sp. and Vitis sp. (ZUR STRASSEN 2003). Due to its widespread distribution this is the first official faunistic record from Slovakia.

Thrips simplex (Morison 1930) is characterized by the following description: antennae composed of 8 segments, interocellar setae placed inside the ocellar triangle, a netlike structure between S1 setae of metanotum and reticles characterised by typical internal microscopic markings, body and legs dark brown, antennal segment 3 and tarsi paler, 3 (sometimes 4) pairs of posteromarginal setae on pronotum, wings paler basally.

Adults emerge milky white, but soon turn brown and being feeding. Eggs are deposited in the leaf tissue and corms. The two larval stages are light yellow and are usually found beneath the leaves or bracts. The fully developed second instar larva is about the size of the adult (DENMARK \& PRICE 1998).

\section{METHODS}

The thrips were sampled within our complex research on Thysanoptera diversity in Slovakia, individually, using the pincers and brush as well as shaking the flowers. AGA solution (alcohol, glycerol, aqua) and ethanol were used as a conservation liquid. Thrips were mounted according to standard preparatory techniques using for thrips (FEDOR et al. 2012; SIERKA \& FEDOR 2004). Thrips simplex specimens were determinated according to ZUR STRASSEN (2003). The material has been deposited in the collections of the authors.

\section{RESULTS AND DISCUSSION}

The first official faunistic record of the introduced gladiolus thrips Thrips simplex (Morison 1930) in Slovakia:

Material examined: 10 specimens were found in SW Slovakia, in the city of Trnava (Fig 1, GPS: $48^{\circ} 21^{\prime} 47,19^{\prime \prime} \mathrm{N}, 17^{\circ} 34^{\prime} 59,52^{\prime \prime} \mathrm{E}$; DFS grid square 7671). August 4, 2015, 2 ^ 8 \% , collected with the brush and pincers from pink-violet gladioli flowers. 28 specimens of the gladiolus thrips were also discovered in the village of Miloslavov (Fig. 1, GPS: $48^{\circ} 06^{\prime} 16,95^{\prime \prime} \mathrm{N}, 17^{\circ} 17^{\prime} 56,5^{\prime \prime}$ E, DFS grid square 7969). August 5, 2015, 14 , sampled by shaking the violet gladioli flowers and using the brush. September 4, 2015, 14 o , obtained by shaking the yellow gladioli flowers and applying the brush. Leg.: R. Masarovič, J. Sigmund, det.: R. Masarovič, coll. R. Masarovič.

The species breeds on gladiolus corms, leaves and flowers and appears to be more numerous on dark flowered cultivars (HERR 1934; HAGREAVES \& COOPER 1980; MILEVOJ et al. 2008). Adults and larvae feed on gladiolus foliage and stalks causing blasting and silvering of leaves. Larvae are full of green chlorophyll, which is clearly visible through the body wall (HERR 1934). The flowers are also deformited and discolorated (HERR 1934; DENMARK \& PRICE 1998). Thrips create silvery white spots on gladiolus flowers which later turn brown (DENMARK \& POE 1972). The gladiolus thrips is probably the most dangerous pest that infests gladioli as it causes damage by sucking and can completely destroy flowers (ZGONEC 1990). 


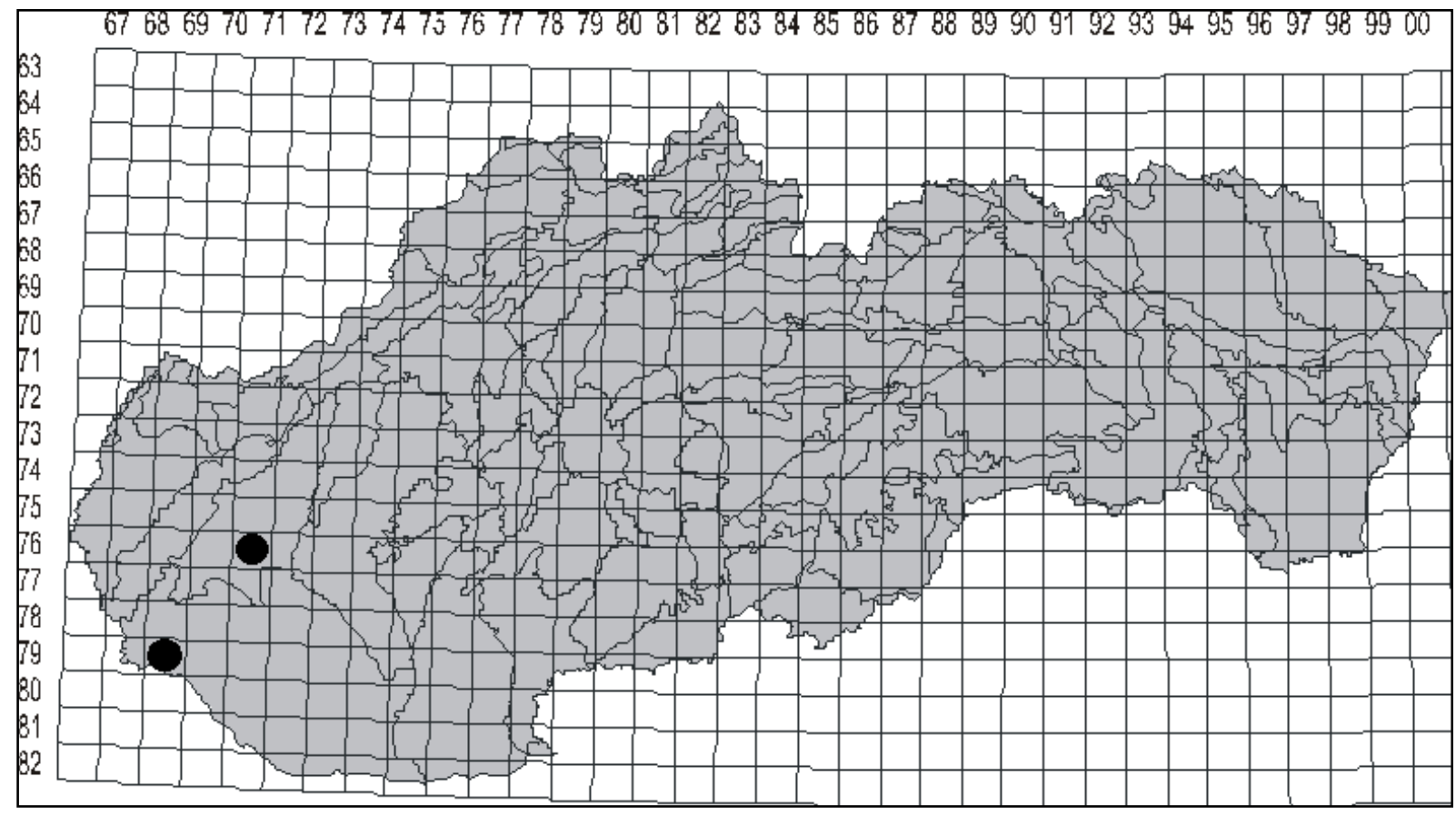

Fig. 1: Study sites with first records of T. simplex in the map of Slovakia

\section{ACKNOWLEDGEMENTS}

The project was financially supported by the project UK/160/2015, VEGA 1/0103/14 and this contribution is also result of the project implementation ITMS 26240120014 "Center of excellence for protection and use of landscape and for biodiversity" supported by the ERDF. Sincere thanks to B. Zajdelová for provided material of thrips.

\section{REFERENCES}

Collins D. W. 1998. Recent interceptions of Echinothrips americanus Morgan (Thysanoptera, Thripidae) imported into England. Entomol. Month. Magaz. 134: 1-3.

Denmark H. A. \& PoE S. L. 1972. The gladiolus thrips, Taeniothrips simplex (Morison) in Florida (Thysanoptera: Thripidae). Florida department of agriculture and consumer services, Division of plant industry. Entomol. Circ. 119: 1-2.

Denmark H. A. \& Price J. F. 1998. Gladiolus thrips, Thrips simplex (Morison) (Insecta: Thysanoptera: Thripidae). University of Florida, DPI Entomol. Circ. 322: 1-3.

FEDOR P. J. \& VARGA L. 2007. The first record of Gynaikothrips ficorum Marchal, 1908 (Thysanoptera) in Slovakia. Thysanopteron. Pismo Entomol. 3(1): 1-2.

FEdor P., DoričovÁ M., MASARoviČ R. \& SIERKA W. 2012. Strapky (Thysanoptera) Slovenska. Comenius University, Bratislava. 184 p.

GOLDARAZENA A. 2011. First record of Thrips hawaiiensis (Morgan, 1913) (Thysanoptera: Thripidae), an Asian pest thrips in Spain. Bulletin OEPP/EPPO (Organisation Europeene et Mediterraneene pour la Protection des Plantes/European and Mediterranean Plant Protection Organization) 41(2): 170-173.

Hagreaves, J. R. \& CoOPer L. P. 1980. Differential susceptibility of some gladiolus cultivars to gladiolus thrips, Taeniothrips simplex (Morison). Queensl. J. Agric. Anim. Sci. 37: 161-163.

HerR E. A. 1934. The gladiolus thrips, Taeniothrips gladioli M. and S. Bulletin, Ohio Agricultural Experiment Station 537: 64.

JENSER G. \& CZENZ K. 1988. Thysanoptera species occurring frequently on cultivated plants in Hungary. Acta Phytopathol. Hun. 23(3-4): 285-289. 
KARAdJOVA O. \& KRUMOV Y. 2003. Echinothrips americanus Morgan (Thysanoptera: Thripidae), a new pest of the Bulgarian Greenhouses. In: Proceedings of the International Scientific Conference at the 50th Anniversary of the University of Forestry, Plant Protection Section, 1-2 April 2003, Sofia., pp. 122-125.

LEWIS T. 1997. Thrips as Crop Pests. CAB International, Wallingford, 740 p.

LEWIS T. 1973. Thrips, their biology, ecology, and economic importance. Academic Press London and New York, $349 \mathrm{p}$.

MASAROVIČ R., DORIČOVÁ M., PROKOP P. \& FEDOR J. 2014. „Testing the limits“ - an interesting record of the exotic banded greenhouse thrips Hercinothrips femoralis (Thysanoptera: Thripidae: Panchaetothripinae) at the high Carpathian mountain altitudes. Biologia 69(11): 1631-1634.

MiLEVOJ L., ZDEŠAR M. \& TRDAN S. 2008. Susceptibility to gladiolus thrips (Thrips simplex [Morison]) in four different coloured gladiolus cultivars. Acta Phytopathol. Hun. 43(2): 323-327.

MORISON G. D. 1930. On a collection of Thysanoptera from South Australia. Bull. Entomol. Res. 21: 9-14.

MorisON G. D. 1957. A review of British glasshouse Thysanoptera. Transactions of the Royal Entomological Society of London 109: 467-534.

Mound L. A. 1997. Biological diversity. In: LEWIS T. (ed.), Thrips as crop pests. CAB International, Oxford and New York, pp. 197-215.

PELIKÁN J. 1989. Nově importovaný škůdce skleníkových rostlin, třasněnka západní, Frankliniella occidentalis (Pergande, 1895). Ochrana Rostlin 25: 271-278.

PELIKÁN J. 1991. Truběnka fikusova (Gynaikothrips ficorum Marchal, 1908) ve sklenících v Československu. Ochrana Rostlin 27: 287-291.

Roditakis E., Mound L. A. \& Roditakis N. E. 2006. First record in Crete of Hercinothrips femoralis in greenhouse banana plantations. Phytoparasitica 34(5): 488-490.

SIERKA W. \& FEDOR P. 2004. Wciornastki (Insecta, Thysanoptera). Universytet Slaski, Katowice.

Trdan S., Jović M. \& AndJus L. 2005. Palm thrips, Parthenothrips dracaenae (Heeger) (Thyanoptera: Thripidae), in Slovenia: still a pest of minor importance? Acta Agric. Slov. 85(2): 211-217.

Trdan S., Milevoj L., RASPUdić E. \& ŽEŽLINA I. 2003. The first record of Echinothrips americanus Morgan in Slovenia. Acta Phytopathol. Hun. 38(1): 157-166.

VARGA L. \& FEDOR P. J. 2008. First interception of the greenhouse pest Echinothrips americanus Morgan, 1913 (Thysanoptera: Thripidae) in Slovakia. Plant Protect. Sci. 44(4): 155-158.

VARGA L. 2008. Hercinothrips femoralis (Reuter, 1891) - a New Pest Thrips (Thysanoptera: Panchaetothripinae) in Slovakia. Plant Protect. Sci. 44(3): 114-118.

VIERBERGEN G. \& DE JONG Y. 2013. Fauna Europaea: Thysanoptera, Thripidae. Fauna Europaea (version 2.6.2). http:// www.faunaeur.org. (accessed 10.05.2014).

Vierbergen G., Cean M., Szeller I. H., Jenser G., Masten T. \& ŠImala M. 2006. Spread of Two Thrips Pests in Europe: Echinothrips americanus and Microcephalothrips abdominalis (Thysanoptera: Thripidae). Acta Phytopathol. Hun. 41(3-4): 287-296.

ZGONEC S. 1990. Bolezni in škodljivci v okrasnem vrtu. Ljubljana, ČZP Kmečki glas, 112 p.

ZUR STRASSEN R. 2003. Die terebranten Thysanopteren Europas und des Mittelmeer-Gebietes. Goecke \& Evers, Keltern. 